\title{
Considering the Role of Zone of Proximal Development and Constructivism in Supporting Teachers' TPACK and Effective Use of Technology
}

\author{
Consideración del papel de la Zona de Desarrollo Próximo y el \\ constructivismo en el apoyo al TPACK de los maestros y al uso efectivo de la \\ tecnología \\ Drew Polly \\ University of North Carolina. Charlotte, USA \\ Drew.Polly@uncc.edu \\ Erik Byker \\ University of North Carolina. Charlotte, USA \\ ebyker@uncc.edu
}

\begin{abstract}
This article examines Vygotsky's (1978) Zone of Proximal Development (ZPD) and Tharp and Gallimore's (1988) application of ZPD for teacher learning that can be used as a framework to develop teachers' and teacher candidates' Technological Pedagogical Content Knowledge (TPACK). We synthesize these ideas and provide vignettes from both teachers and teacher candidates that describe how ZPD can inform the way teachers' TPACK is developed. We argue that the stages of ZPD (Tharp \& Gallimore, 1988) provide a helpful framework for the development of teacher candidates' and in-service teachers' TPACK through experiential learning opportunities that include the reflection of the intersection of technologies, pedagogies, and content knowledge. The implication of our paper includes a call for long-term systematic examinations of strategies to support teachers and teacher candidate development of TPACK.
\end{abstract}

Keywords: constructivism, educational technology, mentoring, TPACK, teacher candidates, technology integration, ZPD

\section{Resumen}

Este artículo examina la Zona de Desarrollo Próximo (ZPD) de Vygotsky (1978) y la aplicación de la ZPD de Tharp y Gallimore (1988) para el aprendizaje docente que puede utilizarse como marco para desarrollar el Conocimiento Tecnológico Pedagógico del Contenido (TPACK, siglas en inglés) de profesores y candidatos a profesores. Sintetizamos estas ideas y proporcionamos viñetas de profesores y candidatos a profesores que describen cómo la ZPD puede indicar la forma en que se desarrolla el TPACK de los profesores. Argumentamos que las etapas de ZPD (Tharp \& Gallimore, 1988) proporcionan un marco útil para el desarrollo del TPACK de profesores candidatos y docentes en servicio a través de oportunidades de aprendizaje experiencial que incluyen el reflejo de la intersección de tecnologías, pedagogías y conocimiento del contenido. La implicación de nuestro artículo 
incluye un llamado a indagaciones sistemáticas a largo plazo, de estrategias para apoyar a los maestros y candidatos a maestros al desarrollo del TPACK.

Palabras clave: constructivismo, tecnología educativa, mentoría, TPACK, candidatos a docentes, integración tecnológica, ZPD.

\section{Considering the Role of Zone of Proximal Development and Constructivism in Supporting Teachers' Integration of Technology}

Technology access is at an all-time high in classrooms for all children of all ages and grade levels around the world (Freeman et al., 2017). School districts and schools have invested money into technological infrastructure, devices, with the hope that technology can be a silver bullet to substantially transform teaching and learning (Polly, 2014; Niess, 2005). Contrary to the optimistic views of educational leaders, research has consistently shown a need to seek more effective ways to prepare both teacher candidates and in-service teachers to integrate technology (Tondeur et al., 2017). In many cases, educational leaders are investing financial resources in developing infrastructure and purchasing devices, but not on investing in teachers (Cuban, 2009; Freeman et al., 2017). More attention must be spent examining theoretically- and empiricallybased ways to support teachers' development of knowledge and skills related to effectively teaching with technology (Byker et al., 2018; Polly \& Rock, 2016).

We argue that such support for teaching with technology is grounded in an understanding of Vygotsky's (1978) Zone of Proximal Development (ZPD). This means that teacher educators scaffold teacher candidates and in-service teachers with engaging experiences where they experience and reflect on technology-rich teaching (Kopcha et al., 2020; Lawless \& Pellegrino, 2005; Niess, 2005; Tondeur et al., 2011). In turn, these technology-rich teaching experiences further assist educators in developing their Technological Pedagogical and Content Knowledge (TPACK) as they learn how to match the uses for technology with the subject content and with effective pedagogies for teaching the content (Mishra \& Koehler, 2006). Thus, our article considers a theoretical intersection of ZPD and mentorship as a conceptual framework that supports the development of educators' TPACK. We provide an overview of ZPD and describe how ZPD can be used to support teachers' TPACK. We then provide vignettes in which aspects of ZPD are highlighted related to the development of teachers' and teacher candidates' TPACK.

\section{Synthesizing Theoretical Constructs and Models Related to Technology Integration}

In this section, we identify and define the theoretical constructs, which we use to frame this article. First, we describe Vygotsky's (1978) ZPD. We then describe TPACK in greater

Considering the Role of Zone of Proximal Development and Constructivism in Supporting Teachers' 
detail (Mishra \& Koehler, 2006; Niess, 2005). We also explain how ZPD is an important feature in the development of teachers' TPACK.

\section{Zone of Proximal Development (ZPD)}

Social constructivism epistemologies posit that learning occurs through meaningful experiences with others. Vygotsky (1978) contends that knowledge is co-constructed and that individuals learn from others during experiences. Within the theory of social constructivism, Vygotsky advanced the idea that each individual has a personal ZPD. As Vygotsky (1978) explained, ZPD is "the distance between the actual development level as determined by independent problem solving and the level of potential development as determined through problem solving under adult guidance or in collaboration with more capable peers" (p. 86). ZPD is anchored in the notion that the development of skills and conceptual knowledge is supported by scaffolding or support from more knowledgeable others, peers, or learning tools. These supports help individuals perform tasks beyond what these individuals can do alone.

While Vygotsky originally conceptualized ZPD as a theory for child development, educational researchers have applied the concept to the development of both teacher candidates and current teachers (e.g., Fani \& Ghaemi, 2011; Tharp \& Gallimore, 1988; Warford, 2011). Tharp and Gallimore (1988) described four stages of ZPD that teachers sequentially progress through (Table 1). Stage I is what most people are familiar with, where learners require support in order to complete a task. Stage II and Stage III reflect successful opportunities for learners to complete tasks independently with minimal support. In Stage II, learners become self-supported and need less scaffolding, while in Stage III, support from others may hinder an individual's performance. As the context in which the task takes place changes, Stage IV involves learners adjusting and modifying how to complete the task based on the context and culture.

\section{Table 1}

Four Stages of ZPD (Tharp \& Gallimore, 1988)

\section{Stage Description}

I Learners engage in a task but are unable to successfully complete it without being supported by modeling, coaching, and other tools such as technology.

II Learners begin to be self-supported and complete the task successfully without assistance.

Considering the Role of Zone of Proximal Development and Constructivism in Supporting Teachers' TPACK and Effective Use of Technology. Drew Polly \& Erik Byker. 
III Learners internalize and make more sense of how to complete the task. Scaffolding may hinder performance in this stage.

IV Learners cycle back through their ZPD modifying and adjusting actions based on context and sometimes lead others through the stages.

Researchers have used ZPD as a framework to explain the development of both teacher candidates and inservice teachers when they have participated in collaborative projects and activities (e.g., Kuusisaari, 2014; Nyikos \& Hashimoto, 1997; Shabani et al., 2010), interacted with a coach or mentor (Polly, 2012; Flores et al., 2011; Haneda et al., 2016), or been supported by technology-based scaffolds and supports (Lai \& Calandra, 2010; Luckin, 2008).

The construct of the ZPD has been widely accepted and used by multiple educational researchers. ZPD provides a way of thinking about how individuals develop skills and knowledge through scaffolding, modeling, coaching, and situated learning (Lave \& Wenger, 1991) supports to guide the transfer of knowledge and skills. ZPD has some commonalities to Merrill's First Principles of Instruction (Merrill, 2002). Merrill (2002) posited that learning is most effective when individuals' prior knowledge is activated, the targeted performance is demonstrated, learners have opportunities to apply their new knowledge multiple times, and their new knowledge is integrated into the learners' world to use it more frequently. While Merrill (2002) advocated for demonstration and modeling from a more knowledgeable other, ZPD focuses more on the scaffolding and guidance of learners through the various stages of performance.

\section{Technological Pedagogical Content Knowledge (TPACK)}

TPACK is a construct that explains the knowledge areas that teachers need in order to effectively integrate technology into their instruction. The framework identifies effective instructional technology integration as the merging of three knowledge areas: technology, pedagogy, and content knowledge (Mishra \& Koehler, 2006; Niess, 2005; Niess et al., 2009). Researchers explain that TPACK is "a useful frame for thinking about what knowledge teachers must have to integrate technology into teaching and how they might develop this knowledge" (Schmidt et al., 2009, p. 125). Teacher educators and researchers have embraced the framework as a tool for thinking about and applying the uses for technology in meaningfully educative ways; especially in the context of preparing teachers to integrate instructional technology in their classrooms (Chai et al., 2010; Voogt et al., 2013). TPACK is typically represented by a triple venn diagram (Figure 1).

Considering the Role of Zone of Proximal Development and Constructivism in Supporting Teachers' TPACK and Effective Use of Technology. Drew Polly \& Erik Byker. 


\section{Figure 1}

TPACK Figure (Reproduced by permission of the publisher, (C) 2012 by tpack.org)

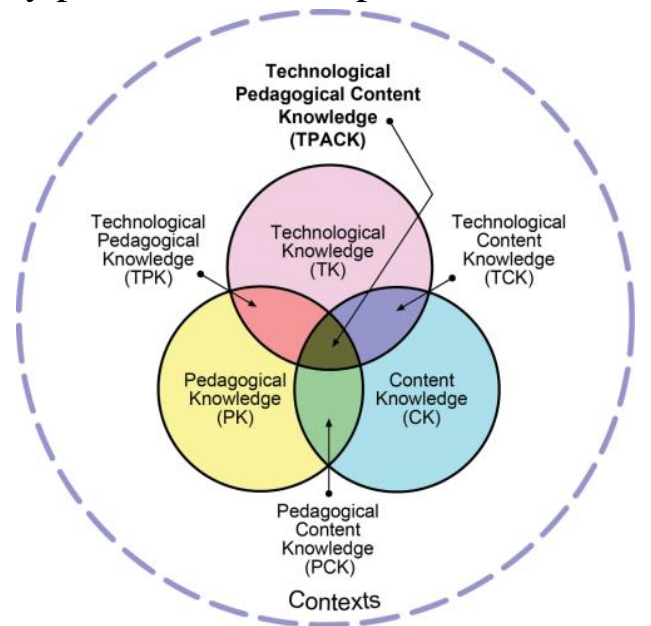

As Figure 1 illustrates, TPACK encompasses three primary components that educators need in order to use technology effectively in the classroom or in whichever instructional context they are situated. As earlier discussed, these knowledge areas are: knowledge of pedagogy (PK), knowledge of technology (TK), and knowledge of content (CK). PK is the pedagogical knowledge an educator possesses in regards to effective teaching methods, practices, and strategies. TK is the knowledge about technological tools. It is important to acknowledge that there are a wide range of tools used in classrooms for everyday learning. For example, a pencil is a tool for writing and a notebook is a tool for compiling content knowledge and showing one's learning. There are also digital tools like laptops and tablets, which often have a wider range of possible uses. Educators use their TK in order to make decisions in regards to what technological tool is the best fit for the instructional goals of a lesson or unit. Thus, TK also encompasses how a technology works and the different applications of that specific technology within the classroom context. CK is the knowledge of content. At each level of schooling (i.e., elementary, middle, secondary, tertiary), there is discipline-specific content knowledge, which the educator has a responsibility for knowing. Likewise, there is content knowledge represented in state standards and district pacing guides, which outlines the scope and sequence of the content knowledge. $\mathrm{CK}$ is often tied to summative assessments and high-stakes testing in order for learners to demonstrate what they were able to master through a unit or period of study.

Figure 1 also illustrates how the TPACK framework includes overlapping areas of knowledge. Perhaps the most familiar overlapping knowledge area is PCK or pedagogical content knowledge. PCK was first popularized by Shulman (1987) and identifies how teacher's pedagogical knowledge and content knowledge merge together for effective classroom teaching. PCK is the convergence of teaching practices and strategies connected with specific content knowledge areas. For example, a teacher may find it is best for students to examine the history of

Considering the Role of Zone of Proximal Development and Constructivism in Supporting Teachers' TPACK and Effective Use of Technology. Drew Polly \& Erik Byker. 
Ellis Island with first-person historical narratives and a simulated role-play of events related to an immigrant's journey to the United States.

Another area of knowledge convergence is technological pedagogical knowledge or TPK, which is the integration of technology with specific pedagogical practices. Revisiting our previous Ellis Island example. A teacher could demonstrate TPK by utilizing an online HyperDoc to guide learners' in their engagement with first-person historical narratives of immigration through Ellis Island.

The final overlap of knowledge areas is technological content knowledge or TCK, which is the knowledge of content-specific applications of technology and the constraints associated with the technology. To demonstrate TCK, a teacher would examine the Ellis Island HyperDoc to ensure the content is age-appropriate and to determine the level of technological skill needed to navigate through the activities.

Taken together, TPACK is the convergence of these overlapping knowledge areas and forms what Shulman (2003) identifies as "the wisdom of practice" (p. 1). This means that as educators recognize how they are integrating their technological knowledge, pedagogical knowledge, and content knowledge they become metacognitive about the ways these knowledge areas inform their practice. Ultimately, such metacognition is in support of fostering an environment of engaged learning among the students in the classroom.

\section{Combining TPACK and ZPD Models}

TPACK is anchored in a theoretical (Mishra \& Koehler, 2006; Niess, 2005; Shulman, 2003) and an empirical foundation (Yeh et al., 2014). We argue that ZPD is especially instructive in guiding teacher educators and professional developers in ways to help support the development of TPACK among preservice and inservice teachers. ZPD includes the notion of scaffolding experiences to: (1) engage learners' curiosity about the instructional technologies, (2) collaboratively play with the instructional technology, (3) reflect on ways to use the instructional technology (4) simplify tasks so they are manageable, and (5) motivate students to pursue the instructional goal. In sum, synthesizing TPACK with ZPD provides a conceptual model to support the development of TPACK of preservice teachers and inservice teachers.

\section{Considering Models to Develop Teacher Candidates' and In-service Teachers' TPACK}

In this section we describe two empirically-based models that have been advanced to develop teacher candidates' and in-service teachers' TPACK. The SQD model (Tondeur et al., 2011) focuses on teacher candidates, while the STAK model (Hutchison, 2012) focuses on inservice teachers.

Considering the Role of Zone of Proximal Development and Constructivism in Supporting Teachers' TPACK and Effective Use of Technology. Drew Polly \& Erik Byker. 


\section{SQD Model}

Tondeur and colleagues (2011) conducted a systematic review and synthesis of 19 qualitative studies that examined how to support teacher candidates' abilities to integrate technology into their teaching. They developed the Synthesis of Qualitative Evidence (SQD) model that included 12 themes, seven of which included empirically-based recommendations to develop teacher candidates' capacity to effectively integrate technology. The SQD themes most relevant to the construct of ZPD are role models and collaboration. These are detailed below.

\section{Role Models}

As one of their key findings, Tondeur and colleagues (2011) found that 13 of the studies that they reviewed included data about the positive influence that role models have on teacher candidates' technology integration skills. These role models included faculty who teach education courses and teachers in schools where they completed clinical practice experiences (Sime \& Priestley, 2005). The systematic literature review also attributed teacher candidates' lack of technology integration to the lack of examples and role models in schools where teacher candidates completed clinical practice experiences (Tearle \& Golder, 2008). More recent research found that teacher candidates' development is more influenced by seeing role models during their practicum experiences in schools than their experiences in teacher education courses (Tondeur et al., 2017).

Role models align to the theory of ZPD, as individuals progress through the four stages with support of others or resources in Stage I. In the case of the articles cited in the study, role models occurred both in teacher education courses and in schools (Tondeur et al., 2011). From the perspective of TPACK, the most potential for development occurs when technology use aligns to the center of the TPACK triple Venn diagram, where teacher candidates and teachers integrate their instructional technology based on the content they teach and with pedagogies that support their learners (Niess, 2005). Research has shown that teacher education programs best help develop teacher candidates' TPACK when their faculty are effective role models for teaching with technology in courses (Byker et al., 2019; Polly et al., in press). Equally important is when candidates complete their clinical practice experiences in classrooms where their mentor teachers are also role models for technology integration (Banas \& York, 2014; Tondeur et al., 2001).

\section{Collaboration}

Collaboration is another aspect of the SQD model. Teacher candidates' reported growth in their ability to teach with technology is often based on co-planning with other teacher candidates and getting feedback on their lesson plans from their peers (Brush et al., 2003). Researchers have also found that teacher candidates benefited from peer collaboration in planning technology-rich activities, but needed feedback from a more knowledgeable other such as an inservice teacher or course instructor (Baran et al., 2019). Further, teacher candidates

Considering the Role of Zone of Proximal Development and Constructivism in Supporting Teachers' 
reported the need for structure around collaborative activities beyond simply permission to work with other teacher candidates (Yeh et al., 2014).

\section{STAK Model}

Through a national research study, teachers provided feedback about what they need to effectively integrate technology in their teaching. Their open-ended responses were analyzed and organized into four categories: Support, Time, Access, and Knowledge, which has been termed the STAK model (Hutchison, 2012; Woodward \& Hutchison, 2018). In a national survey leading to the STAK model, teachers reported a need for:

1) Sufficient ongoing Support for integration

2) Time to plan for integration with support from integration experts and fellow teachers

3) Access to models and mentors

4) Developing supports that are specific to each teacher's background Knowledge (Woodward \& Hutchison, 2018, p. 615)

Each of the four aspects of the STAK model align to Vygotsky's construct of ZPD, and Tharp and Gallimore's (1988) views about how ZPD could be used to explain teacher learning. The first aspect, support, speaks to the fact that teachers value support from more knowledgeable others. In fact, the individual support nearby from a teacher, instructional coach, or professional development facilitator may be enough to convince teachers to integrate technology compared to simply attending a workshop on technology integration (Colburn, 2019; Glazer et al., 2009; Harris, 2016).

The second aspect, time, has been discussed in multiple studies related to technology integration, with a specific focus that teachers need time to explore and learn how to use technologies, plan ways in which technology can enhance teaching and learning, and prepare to teach with technology (Johnston et al., 2019; Koh et al., 2017; Young et al., 2019). The third aspect, access, focuses on individuals having access to mentors and models to support technology integration efforts. Studies have found that these mentors and models could be individuals in their school building, technology-based resources, or artifacts such as videos of classroom teaching or lesson plans (Johnston et al., 2018; Koh, 2019; Smits et al., 2019).

The last aspect of the STAK model, knowledge, focuses on developing background knowledge related to technology integration. Several studies have studied the impact of TPACKfocused professional development and found that the most effective models align with researchbased approaches to teacher professional development (Lawless \& Pellegrino, 2007). These approaches focus on student learning, advocate for technology as a tool to support teaching and learning, actively engage teachers in learning technology, content, and pedagogies, and provide ongoing support (e.g., Polly \& Hannafin, 2010; Koh et al., 2017; Lawless \& Pellegrino, 2007; Tai, 2015; Tsai \& Chai, 2012).

Considering the Role of Zone of Proximal Development and Constructivism in Supporting Teachers' TPACK and Effective Use of Technology. Drew Polly \& Erik Byker. 


\section{Synthesis of SQD and STAK Models}

In this section we described two research-based models for developing teacher candidates' and in-service teachers' TPACK. Both the SQD and STAK model include ideas that align to Vygotsky's construct of ZPD as well as Tharp and Gallimore's stages of ZPD for teachers. In the next section, we provide vignettes to describe how teacher educators and professional development facilitators can operationalize these models and ZPD.

\section{Vignettes on Using ZPD to Develop TPACK}

In this section, we provide vignettes of how both teacher candidates and inservice teachers' TPACK can be developed through the ZPD framework. For each vignette, we describe how the example is rooted in theory and describe the outcomes of the vignette. The vignettes occurred in the suburbs of a major city in the Southeastern region of the United States.

\section{Teacher Candidates' Creation of an Educational Game}

\section{Overview}

This vignette took place at a large university near a major city in the southeastern United States that educates over 28,000 students. The elementary education program, in which this course took place, graduates between 150 and 175 teacher candidates each year. In an undergraduate course - taught by the first author - teacher candidates played an educational game housed in Microsoft PowerPoint and then built their own game from scratch. For this game, they created a scenario, rules, questions, feedback slides, and constructed all of the behind the scene links so that the game worked in presentation mode. Candidates were all elementary education majors and were either sophomores or juniors enrolled in the course which focused on instructional design, lesson planning, assessment, and technology integration.

The course session took place in a typical university classroom with tables and chairs, but students either brought their personal laptop or students borrowed a university-provided one for the class period. The class session started with the first author-who was the course instructorexplaining a simulation scenario in which the candidates were fourth grade students in a local school. The first author then provided detailed directions and modeled how to start the game. Teacher candidates played the educational game in table groups for 10 minutes while the first author observed, asked individuals follow-up questions, and troubleshooted technology issues if any occurred. The most typical technology issue was teacher candidates playing the game in "edit" mode — which disabled the links and the game's functionality — instead of in presentation mode.

Considering the Role of Zone of Proximal Development and Constructivism in Supporting Teachers' TPACK and Effective Use of Technology. Drew Polly \& Erik Byker. 
After teacher candidates played the game, the first author modeled how to debrief the activity by facilitating a discussion about which questions were difficult, and what connections teacher candidates noticed between the questions and the course content that they had worked with in a previous unit. The game included questions on North Carolina Social Studies content that they had been using as a topic for a lesson plan that they had recently completed. Following the discussion the first author provided a printed handout and modeled to the teacher candidates how to build their own version of the game by creating various slides in PowerPoint and then linking them together.

\section{Application of Theories}

The first author served as the role model by allowing teacher candidates to experience the game as learners while he modeled how to give instructions, facilitate the activity, and debrief the activity in a discussion. The first author also modeled how to build the game with a printed handout as well as through a step-by-step demonstration. Teacher candidates collaborated in groups of 3 or 4 on their activity and provided support to each other as they built the activity. As teacher candidates constructed their game, they needed less support and depended less on the handout and the directions since they had internalized the process of building the educational game.

\section{Influence on Teacher Candidates}

Working in collaborative groups, teacher candidates successfully built their own educational game in PowerPoint. The questions included in the game aligned to state standards being learned by children they were working with, and included a range of difficulty, which was an objective of the course and the activity. Further, some teacher candidates talked to the teacher in the school where they were completing their clinical practice experience, and were able to use their educational game with students in either a small group or whole group context. Teacher candidates shared reflections that they were at first intimidated by the technological aspects of building the entire game, including the links in PowerPoint, but after seeing it demonstrated and working with the technology, they felt as if they had accomplished something important.

\section{Inservice Teachers Examining a Mathematics Problem Solving Program}

\section{Overview}

The first author served as a professional development facilitator for groups of teachers in a school and provided teachers with information about the Thinking Blocks Subtraction program, which is a free website and iPad application (https://www.mathplayground.com/tb_addition/index.html). The school is in the middle of a mid-size city in the southeastern United States. The first author provided time for teachers to explore the program at first to see if they could figure out how to use it. The program requires learners to label and identify quantities in a math problem and build a model of the math task

Considering the Role of Zone of Proximal Development and Constructivism in Supporting Teachers' 
using rectangular bars before working with numbers (Figure 2). After learners correctly set the problem up correctly, learners could then work with numbers and solve the task. The course instructor used a series of questions to help launch the activity and support students' work in the app.

\section{Figure 2}

Screen Capture from Thinking Blocks Subtraction iPad App

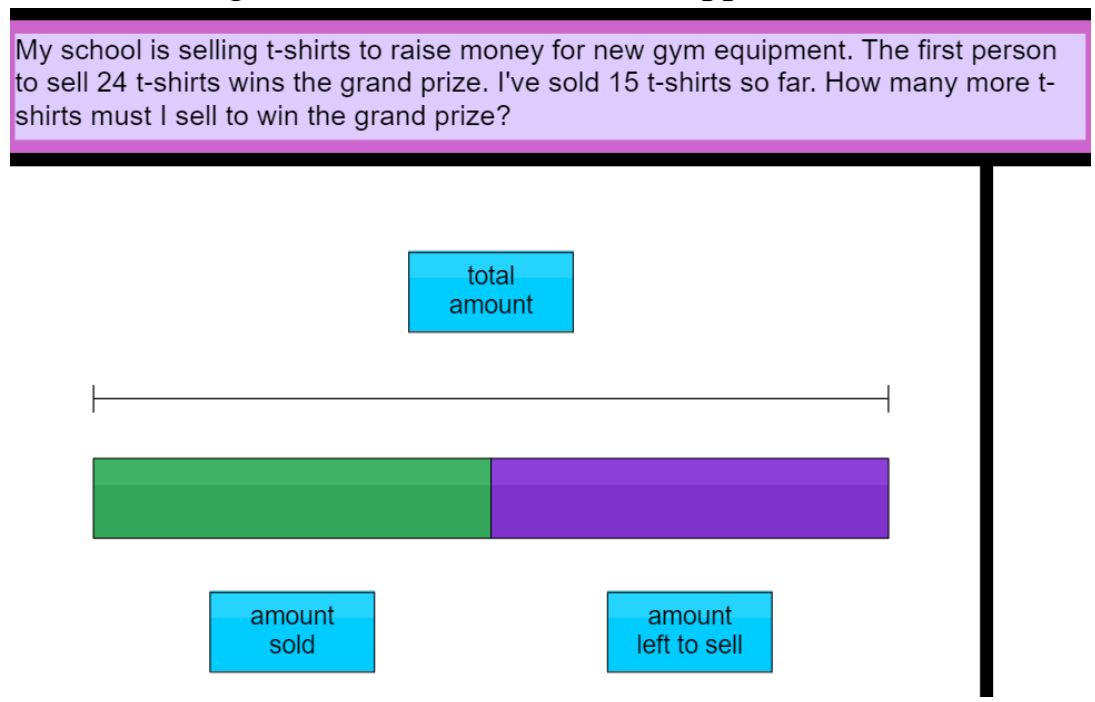

\section{Application of Theories}

As the more knowledgeable other, the first author operationalized the Zone of Proximal Development by providing support and scaffolds while simultaneously allowing teacher candidates to have to determine how to use the program themselves. Further, there was support between teachers as they collaborated with each other to explore the tasks in the iPad app.

After initially engaging with the program as learners, teachers had the opportunity to analyze how they would use this with their students, how they would introduce the program to students, and what questions they would ask students. The first author's intent was to provide opportunities to develop teachers' TPACK with this specific program.

\section{Influence on Teachers}

Teachers became more comfortable with using the program as learners, experienced pedagogies used by the first author to set up the activity and scaffold their experience, and engaged in productive struggle trying to figure out where to put the labels and bars for each task (see Figure 2). Lastly, the first author provided opportunities to discuss how they would use it with their own students and what that would look like in their classroom.

During a follow-up meeting, two teachers reported that they had tried the program with their students. Others were interested in learning about how the use of the program went, and during the meeting the two teachers provided more detail and support to the other teachers about

Considering the Role of Zone of Proximal Development and Constructivism in Supporting Teachers' TPACK and Effective Use of Technology. Drew Polly \& Erik Byker. 
how they could possibly use it and set it up. This process shifted the modeling and support from the first author who only visited the school a few times each year to the teachers who worked daily with their colleagues down the hall in the school building.

\section{Synthesis of Vignettes}

The two vignettes illustrate ways of supporting teacher candidates (Vignette 1) and inservice teachers (Vignette 2) through the Zone of Proximal Development, as elaborated on by Tharp and Gallimore (1988). Table 2 describes the various ZPD stages demonstrated in the vignettes. Stage I of the framework is where both of these vignettes started and focused for most of the activities where both teacher candidates and in-service teachers participated in technologyrich activities as learners. The first author provided modeling and ongoing support about how to build an educational game (teacher candidates' vignette) or use an internet-based mathematics activity (in-service teachers' vignette). In both vignettes, teacher candidates and in-service teachers collaborated with each other as learners while the first author modeled the activities. They also collaborated during planning and discussion as they worked on building the educational game (teacher candidates' vignette) and shared how they would use the program with their students (in-service teachers' vignette).

Stage II was evident in both vignettes as teacher candidates used the printed handout, opportunities to collaborate with each other, and follow up conversations with the first author to get support. These approaches align to ideas-like the importance of collaboration and supportin both the SQD and the STAK models. Stage III was evident with some of the teacher candidates and in-service teachers. The teacher candidates in Stage III relied solely on their memory and internalized recollection about how to build the educational game in PowerPoint. In the case of inservice teachers, two teachers utilized the internet-based program in the classroom with their students without additional scaffolding and support. Stage IV was only evident as some teacher candidates and inservice teachers reentered Stage 1 as more knowledgeable others to support classmates, colleagues, and peers.

\section{Table 2}

Alignment of Vignettes to Tharp and Gallimore's (1988) Construct of ZPD

\section{Vignette 1: Teacher Candidates Designing a Digital Game}

Vignette 2: In-service Teachers Analyzing a MathematicsApp

\begin{tabular}{cll} 
Stage I & $\begin{array}{l}\text { Teacher candidates simulated a fourth-grade } \\
\text { classroom and played an educational game } \\
\text { using technology. Candidates collaborated }\end{array}$ & $\begin{array}{l}\text { First author led an activity where } \\
\text { teachers participated as learners using } \\
\text { the technology, completing the }\end{array}$ \\
\hline
\end{tabular}

Considering the Role of Zone of Proximal Development and Constructivism in Supporting Teachers' TPACK and Effective Use of Technology. Drew Polly \& Erik Byker. 


\begin{tabular}{lll}
\hline & $\begin{array}{l}\text { while playing the game, and constructed } \\
\text { their own game. The first author modeled } \\
\text { how to give instructions, facilitated the } \\
\text { game, debriefed the game, provided a } \\
\text { printed handout, and demonstrated how to } \\
\text { build a game in PowerPoint, while teacher } \\
\text { candidates collaborated on it. }\end{array}$ & $\begin{array}{l}\text { activity, engaging in specific } \\
\text { pedagogies, and discussing how it } \\
\text { would be used in their own } \\
\text { classroom. In-service teachers } \\
\text { collaborated during the meeting to } \\
\text { discuss how to use the activity with } \\
\text { students. }\end{array}$ \\
\hline Stage II & $\begin{array}{l}\text { Teacher candidates collaborated, used the } \\
\text { printed handout, and recalled the } \\
\text { demonstration to build their own digital, } \\
\text { educational game. }\end{array}$ & $\begin{array}{l}\text { Two teachers used the program on } \\
\text { their own recalling the model and } \\
\text { support from the meeting, and talking } \\
\text { with each other. }\end{array}$ \\
\hline $\begin{array}{l}\text { Stage } \\
\text { III }\end{array}$ & $\begin{array}{l}\text { Teacher candidates started to automotize } \\
\text { the process and relied less on lesson } \\
\text { scaffolds and models while building the } \\
\text { game. }\end{array}$ & $\begin{array}{l}\text { The same two teachers used it } \\
\text { separately in their classroom with } \\
\text { students. }\end{array}$ \\
\hline $\begin{array}{l}\text { Stage } \\
\text { IV }\end{array}$ & $\begin{array}{l}\text { Three to four teacher candidates continued } \\
\text { to struggle with building the game and two } \\
\text { group members served as role models and } \\
\text { supported the struggling candidates. }\end{array}$ & $\begin{array}{l}\text { In a follow-up meeting the two } \\
\text { teachers shared their experience with } \\
\text { their colleagues and served as the } \\
\text { role models and scaffolds for them. }\end{array}$ \\
\hline
\end{tabular}

\section{Implications and Future Directions}

In this section we describe implications for both research and practice related to future directions for developing teacher candidates' and in-service teachers' TPACK using the theoretical construct of ZPD.

\section{Implications for Research}

Vygotsky's construct Zone of Proximal Development and the elaboration of the Stages of ZPD (Tharp \& Gallimore, 1988) has potential to form a theoretical foundation for developing teacher candidates' and inservice teachers' TPACK. While the framework makes sense operationally, there is a need for research studies that examine how ZPD can be leveraged using faculty in courses and teachers in schools who host teacher candidates simultaneously. In the vignettes provided above, teacher candidates and in-service teachers were introduced to new

Considering the Role of Zone of Proximal Development and Constructivism in Supporting Teachers' TPACK and Effective Use of Technology. Drew Polly \& Erik Byker. 
technology-rich activities and new technologies in either a university-based course or a professional development meeting.

In the context of teacher education and developing the TPACK of teacher candidates, there are rich opportunities to study the interplay between university-based courses and school settings, the impact of the activities in courses, the influence of school settings, as well as the alignment between what teacher candidates experience in courses and what they observe and do in schools during practicum experiences. With inservice teachers and continuing professional development, there is a need for researchers to conduct studies that examine who is modeling and supporting technology integration (Polly et al., 2020), what the influence of the modeling and support is (Byker et al., 2019), and how to effectively move teachers through the ZPD stages described by Tharp and Gallimore (1988). Further, there is a need to examine how teachers' movement through ZPD influences their teaching and their students' learning.

Guskey (2002) advocates for multi-level examinations of teacher learning which include five levels: (1) teachers' reactions to their experience, (2) teachers' increase of knowledge and skills, (3) teachers application of knowledge and skills, (4) teachers' impact on their students' learning, and (5) the impact on the organization of schools, districts, or other systems. Research needs to go beyond initial levels and systematically examine efforts to examine how teachers' apply TPACK in their practice, how these applications of TPACK impact student learning, and how these initiatives impact the school as an organization. Research that examines ZPD must consider the multiple levels that Guskey (2002) identifies within the same study.

\section{Implications for Practice}

Regarding TPACK, the goal of developing TPACK remains equipping teacher candidates and in-service teachers with the knowledge to use technology as a tool to enhance their teaching and their students' learning. To that end we offer three recommendations related to using ZPD to develop TPACK: focused learning goals, appropriate scaffolds, and worthwhile collaborative experiences.

The TPACK model is broad with the three large aspects and the intersections of those aspects. To that end, efforts that educator preparation programs undertake to develop TPACK need to be focused. We contend that for TPACK to be understood, the focus needs to be on the center of the triple Venn diagram, which means that most activities should provide opportunities for teacher candidates to consider the intersection of technology, applied to specific examples from content areas, and further integrated with research-based pedagogies that align with the technology and content. For example, in Vignette 1, teacher candidates used PowerPoint technology to develop an interactive game that aligned with specific content in social studies and considered the pedagogical ways in which the game would guide students' learning.

Considering the Role of Zone of Proximal Development and Constructivism in Supporting Teachers' TPACK and Effective Use of Technology. Drew Polly \& Erik Byker. 
Another important consideration for putting ZPD into practice is the use of appropriate scaffolds. ZPD is built inherently on the idea that a learner needs to be supported and scaffolded by a more knowledgeable other or some other scaffold. If the scaffold and support decreases the rigor too much, then the learner does not engage in productive struggle, which means they may not engage in deep learning from the experience. Hence, scaffolds and the work of more knowledgeable others cannot do all of the work and heavy lifting for the learners. For example, consider the description of the digital activity analysis. The course instructor provided questions and prompts to support teacher candidates' creation of criteria to evaluate the digital programs. Since the teacher candidates created the criteria, it was relevant and meaningful to them and they had engaged in higher-level thinking while considering characteristics of effective digital programs.

Further, both educator preparation programs and those working with in-service teachers need to consider what constitutes worthwhile collaborative experiences. These experiences should be situations where the combined thinking and work significantly adds to the learning experience. In the case of ZPD, the more knowledgeable other and the scaffolds could come from other learners and peers. For example, in the teacher candidates' vignette, they worked together to figure out how to use the app to set up, represent, and solve math problems. From there they took turns practicing how to teach concepts using the app and exchanged feedback with each other. In each of those activities the scaffolding and support from peers greatly enhanced the experience. Additionally, framing this collaborative experience as a time to play with technology (Byker, 2017) further supports the ZPD notion of scaffolding learning experiences through social constructivism.

The various stages of ZPD (Tharp \& Gallimore, 1988) have potential to serve as a framework for the development of teacher candidates' and in-service teachers' TPACK. We acknowledge that there are limitations to this type of framework for TPACK development when it is not integrated through an educator preparation program plan or only part of a stand-alone technology course during a learner's first year or sophomore year of higher education. The foundation of this idea is the recognition that TPACK requires a continuum of learning opportunities to address the intersection of technologies, pedagogies, and content. To that end, educational technology faculty or technology-focused professional developers cannot work in isolation, and their work is always enhanced when they work with and get feedback from experts in pedagogy and content.

Presentación del manuscrito / Received: 15 de junio de 2020

Fecha de aprobación / Accepted: 14 de agosto de 2020

Fecha de publicación / Published: 30 de septiembre de 2020

Considering the Role of Zone of Proximal Development and Constructivism in Supporting Teachers' TPACK and Effective Use of Technology. Drew Polly \& Erik Byker. 
Polly, D. \& Byker, E. (2020). Considering the Role of Zone of Proximal Development and Constructivism in Supporting Teachers' TPACK and Effective Use of Technology. RED. Revista Educación a Distancia, 20(64). http://dx.doi.org/10.6018/red.408661

\section{Funding}

This research has not received any specific grant from funding agencies in the public, commercial or non-profit sectors.

\section{References}

Banas, J. R., \& York, C. S. (2014). Authentic learning exercises as a means to influence preservice teachers' technology integration self-efficacy and intentions to integrate technology. Australasian Journal of Educational Technology, 30(6), 728-746.

Baran, E., Bilici, S. C., \& Sari, A. A. (2019). Investigating the impact of teacher education strategies on preservice teachers' TPACK. British Journal of Educational Technology, 50(1), 357-370. https://doi.org/10.1111/bjet.12565

Brush, T., Glazewski, K., Rutowski, K. et al. (2003). Integrating technology in a field-based teacher training program: The PT3@ASU project. Educational Technology Research \& Development, 51, 57-72. https://doi.org/10.1007/BF02504518

Byker, E. J. (2017). I Play I Learn: Introducing Technological Play Theory. In E. J. Byker et al. (Eds.), Preparing Teacher-Scholars to Inquire: Constructing the Inquiry Processing Cycle (pp. 297-306). Hershey, PA: IGI Global.

Byker, E. J., Putman, S. M., Handler, L. \& Polly, D. (2018). Examining elementary education teachers and pre-service teachers' self-efficacy related to Technological Pedagogical and Content Knowledge (TPACK). In C. Hodges (Ed.), Self-Efficacy in Instructional Technology Contexts (p. 119-140). Springer: New York.

Chai, C. S., Koh, J. H. L., Tsai, C.-C. (2010). Facilitating preservice teachers' development of technological, pedagogical, and content knowledge (TPACK). Journal of Educational Technology \& Society, 13(4), 63-73.

Colburn, S. W. (2019). A collective case study to examine teachers' perceptions of peer coaching for technology integration and its influences on teachers' knowledge and effectiveness. Unpublished doctoral dissertation. Houston Baptist University.

Cuban, L. (2009). Oversold and underused. Boston: Harvard University Press.

Fani, T. \& Ghaemi, F. (2011). Implications of Vygotsky's Zone of Proximal Development (ZPD) in teacher education: ZPTD and self-scaffolding. Procedia- Social and Behavioral Sciences, 29, 1549-1554. https://doi.org/10.1016/j.sbspro.2011.11.396

Flores, B. B., Hernandez, A., Garcia, C. T., \& Clayes, L. (2011). Teacher academy induction learning community: Guiding teachers through their zone of proximal development. Mentoring \& Tutoring, 19(3), 365-389.

Considering the Role of Zone of Proximal Development and Constructivism in Supporting Teachers' TPACK and Effective Use of Technology. Drew Polly \& Erik Byker. 
Freeman, A., Adams Becker, S., Cummins, M., Davis, A., \& Giesinger, C. (2017). NMC/CoSN horizon report: 2017 K-12 Edition. Austin, TX: The New Media Consortium.

Glazer, E. M., Hannafin, M. J., Polly, D., \& Rich, P. (2009). Factors and interactions influencing technology integration during situated professional development in an elementary school. Computers in Schools, 26(1), 21-39.

Guskey, T. R. (2002). Does it make a difference? Evaluating professional development. Educational Leadership, 59(6), 45-51.

Haneda, M., Teemant, A., \& Sherman, B. (2016). Instructional coaching through dialogic interaction: Helping a teacher to become agentive in her practice. Language and Education, 31(1), 46-64. https://doi.org/10.1080/09500782.2016.1230127

Harris, J. (2016). Inservice teachers' TPACK development: Trends, models, and trajectories. In M. Herring, M. Koehler, \& P. Mishra (Eds.), Handbook of Technological Pedagogical Content Knowledge for Educators (2nd ed.) (pp. 191-205). New York, NY: Routledge.

Herring, M. C., Koehler, M. J., Mishra, P., Rosenberg, J. M., \& Teske, J. (2016). Introduction to the second edition of the TPACK handbook. In M.C. Herring, M.J. Koehler, and P. Mishra (Eds.), Handbook of Technological Pedagogical Content Knowledge (TPACK) for Educators (2nd Edition, pp. 1-8). New York: Routledge.

Hutchison, A. (2012). Literacy teachers perceptions of professional development that increases integration of technology into literacy intruction. Technology, Pedagogy, and Education Journal, 21(1), 37-56. http://doi.org/10.1080/1475939X.2012.659894

Johnston, K., Hadley, F., \& Waniganayake, M. (2019). Practitioner inquiry as a professional learning strategy to support technology integration in early learning centres: Building understanding through Rogoff's planes of analysis. Professional Development in Education, 46, 49-64. https://doi.org/10.1080/19415257.2019.1647871

Johnston, K., Highfield, K., \& Hadley, F. (2018). Supporting young children as digital citizens: The importance of shared understandings of technology to support integration in playbased learning. British Journal of Educational Technology, 49(5), 896-910. https://doi.org/10.1111/bjet.12664

Koh, J. H. L. (2019). TPACK design scaffolds for supporting teacher pedagogical change. Educational Technology Research \& Development, 67(2), 577-595. https://doi.org/10.1007/s11423-018-9627-5

Koh, J. H. L., Cha, C. S., \& Lim, W. Y. (2017). Teacher professional development for TPACK21CL: Effects on teacher ICT integration and student outcomes. Journal of Educational Computing Research, 55(2), 172-196. https://doi.org/10.1177\%2F0735633116656848

Kopcha, T. J., Neumann, K. L., Ottenbreit-Leftwich, A., \& Pitman, E. (2020). Process over product: the next evolution of our quest for technology integration. Educational Technology Research and Development, 68(1), 1-21.

Considering the Role of Zone of Proximal Development and Constructivism in Supporting Teachers' TPACK and Effective Use of Technology. Drew Polly \& Erik Byker. 
Kuusisaari, H. (2014). Teachers at the zone of proximal development- collaboration promoting or hindering the development process. Educational Theory, 43, 46-57. https://doi.org/10.1016/j.tate.2014.06.001

Lai, G. \& Calandra, B. (2010). Examining the effects of computer-based scaffolds on novice teachers' reflective journal writing. Educational Technology Research and Development, 58, 421-437. https://doi.org/10.1007/s11423-009-9112-2

Lave, J., \& Wenger, E. (1991). Situated learning: legitimate peripheral participation. Cambridge, UK: Cambridge University Press.

Lawless, K. A., \& Pellegrino, J. W. (2007). Professional development in integrating technology into teaching and learning: knowns, unknowns, and ways to pursue better questions and answers. Review of Educational Research, 77(4), 575-614. https://doi.org/10.3102/0034654307309921

Luckin, R. (2008). The learner centric ecology of resources: A framework for using technology to scaffold learning. Computers \& Education, 50(2), 449-462. https://doi.org/10.1016/j.compedu.2007.09.018

Merrill, M.D. (2002). First principles of instruction. Educational Technology, Research and Development, 50(3), 43-59.

Mishra, P., \& Koehler, M. J. (2006). Technological pedagogical content knowledge: A framework for integrating technology in teacher knowledge. Teachers College Record, 108(6), 1017-1054.

Niess, M. L. (2005). Preparing teachers to teach science and mathematics with technology: developing a technology pedagogical content knowledge. Teaching and Teacher Education, 21(2), 509-523.

Niess, M. L., Ronau, R. N., Shafer, K. G., Driskell, S. O., Harper, S. R., Johnston, C., Browning, C., Ozgun-Koca, S. A., \& Kersaint, G. (2009). Mathematics teacher TPACK standards and development model. Contemporary Issues in Technology and Teacher Education, 9(1). https://citejournal.org/volume-9/issue-1-09/mathematics/mathematics-teachertpack-standards-and-development-model

Nyikos, M., \& Hashimoto, R. (1997). Constructivist theory applied to collaborative learning in teacher education: In search of ZPD. Modern Language Journal, 81(4), 506-517. https://doi.org/10.2307/328893

Polly, D. (2012). Supporting mathematics instruction with an expert coaching model. Mathematics Teacher Education and Development, 14(1), 78-93.

Polly, D. (2014). Elementary school teachers' use of technology during mathematics teaching. Computers in the Schools: Interdisciplinary Journal of Practice, Theory, and Applied Research, 31(4), 271-292.

Polly, D., Byker, E., Putman, S. M., \& Handler, L. K. (in press). Preparing elementary education

Considering the Role of Zone of Proximal Development and Constructivism in Supporting Teachers' TPACK and Effective Use of Technology. Drew Polly \& Erik Byker. 
teacher candidates to teach with technology: The role of modeling. Journal of Digital Learning in Teacher Education. https://doi.org/10.1080/21532974.2020.1795953

Polly, D. \& Hannafin, M. J. (2010). Reexamining technology's role in learner-centered professional development. Educational Technology Research and Development, 58(5), 557-571. doi:10.1007/s11423-009-9146-5.

Polly, D., \& Rock, T. C. (2016). Elementary education teacher candidates' integration of technology in the design of interdisciplinary units. Tech Trends: Linking Research \& Practice to Improve Learning, 60(4), 336-343. doi:10.1007/s11528-016-0059-y

Schmidt, D. A., Baran, E., Thompson, A. D., Mishra, P., Koehler, M. J., \& Shin, T. S. (2009). Technological pedagogical content knowledge: The development and validation of an assessment instrument for preservice teachers. Journal of Research on Technology in Education, 42(2), 123-149. https://doi.org/10.1080/15391523.2009.10782544

Shabani, K., Khatib, M., \& Ebadi, S. (2010). Vygotksy's zone of proximal development: Instructional implications and teachers' professional development. English Language Teaching, 3(4), 237-248.

Shulman, L. (1987). Knowledge and teaching: Foundations of the new reform. Harvard Educational Review, 57(1), 1-23.

Shulman, L. S. (2003). Learning to teach: Sharing the wisdom of practice. New York: Carnegie Foundation for the Advancement of Teaching.

Sime, D., \& Priestley, M. (2005). Student teachers' first reflections on information and communications technology and classroom learning: Implications for initial teacher education. Journal of Computer Assisted Learning, 21, 130-142. https://doi.org/10.1080/13674580701687807

Smits, A., Voogt, J., \& van Velze, L. (2019). The development of technology integration in a graduate course for practicing teachers. In M. L. Niess, H. Gillow-Wiles, \& C. Angeli (Eds.), Handbook of Research on TPACK in the Digital Age (p. 92-112). Hershey, PA: IGI Global. https://doi.org/10.1007/s11423-018-9627-5

Tai, S.-J. D. (2015). From TPACK-in-action workshops to classrooms: CALL competency developed and integrated. Language Learning \& Technology, 19(1), 139-164.

Tearle, P., \& Golder, G. (2008). The use of ICT in the teaching and learning of physical education in compulsory education: how do we prepare the workforce of the future? European Journal of Teacher Education, 31(1), 55-72.

Tharp, R. G. \& Gallimore, R. (1988). Rousing minds to life: Teaching, learning and schooling in social context. Cambridge, UK: Cambridge University Press.

Tondeur, J., Roblin, N. P., van Braak, J., Voogt, J., \& Prestridge, S. (2017). Preparing beginning teachers for technology integration in education: ready for take-off? Technology, Pedagogy, and Education, 26(2), 157-177. https://doi.org/10.1080/1475939X.2016.1193556

Considering the Role of Zone of Proximal Development and Constructivism in Supporting Teachers' TPACK and Effective Use of Technology. Drew Polly \& Erik Byker. 
Tondeur, J., van Braak, J., Sang, G., Voogt, J., Fisser, P., \& Ottenbreit-Leftwich, A. (2011). Preparing teacher candidates to integrate technology in education: A synthesis of qualitative evidence. Computers \& Education, 59(1), 134-144. https://doi.org/10.1016/j.compedu.2011.10.009

Tsai, C.C., \& Chai, C. S. (2012). The "third"-order barrier for technology-integration instruction: Implications for teacher education. Australasian Journal of Educational Technology, 28(6). https://doi.org/10.14742/ajet.810

Voogt, J., Fisser, P., Pareja Roblin, N., Tondeur, J. \& van Braak, J. (2013). Technological pedagogical content knowledge : A review of the literature. Journal of Computer Assisted Learning, 29(2), 109-121.

Vygotsky, L. S. (1978). Mind in society: The development of higher psychological processes. Cambridge, MA: Harvard University Press.

Warford, M. K. (2011). The zone of proximal teacher development. Teaching and Teacher Education, 27(2), 252-258. https://doi.org/10.1016/j.tate.2010.08.008

Woodward, L. \& Hutchison, A. (2018). The STAK model: Exploring individualized professional development for technology integration in literacy. Journal of Technology and Teacher Education, 26(4), 613-644.

Yeh, Y., Hsu, Y., Wu, H., Hwang, F. \& Lin, T. (2014). Developing and validating technological pedagogical content knowledge-practical (TPACK-practical) through the Delphi survey technique. British Journal of Educational Technology, 45(2), 707- 722.

Young, J. R., Young, J., Hamilton, C., \& Pratt, S. S. (2019). Evaluating the effects of professional development on urban mathematics teachers TPACK using confidence intervals. REDIMAT, 8(3), 312-338. https://doi.org/10.17583/redimat.2019.3065

Considering the Role of Zone of Proximal Development and Constructivism in Supporting Teachers' TPACK and Effective Use of Technology. Drew Polly \& Erik Byker. 